\title{
A fala nas diferentes modalidades de reabilitação oral protética em idosos $* * * * * *$
}

\author{
Speech in different oral prosthetic rehabilitation modalities for \\ elderly individuals
}

\author{
Lidiane Cristina Barraviera Rodrigues* \\ Luiz Fernando Pegoraro** \\ Alcione Ghedini Brasolotto*** \\ Giédre Berretin-Felix**** \\ Katia Flores Genaro*****
}

*Fonoaudióloga. Mestre em

Fonoaudiologia pelo Programa de PósGraduação em Fonoaudiologia da

Faculdade de Odontologia de Bauru da Universidade de São Paulo (FOB USP). Professora do Departamento de Fonoaudiologia da Faculdade São Lucas de Porto Velho - RO. Endereço para correspondência: Rua Pio XII, 1258 - Apto. 602 - Porto Velho - RO CEP 78903-036 (lidicbr@hotmail.com).

**Dentista. Professor Titular do Departamento de Prótese da FOB - USP.

***Fonoaudióloga. Doutora em Ciências dos Distúrbios da Comunicação Humana pela Universidade Federal de São Paulo (Unifesp). Professora Doutora do Departamento de Fonoaudiologia da FOB - USP.

****Fonoaudióloga. Doutora em Fisiopatologia em Clínica Médica: Área de Concentração Metabolismo e Nutrição pela Faculdade de Medicina de Botucatu da Universidade Estadual de São Paulo (Unesp). Professora Doutora do Departamento de Fonoaudiologia da FOB - USP

*****Fonoaudióloga. Livre-Docente pelo Departamento de Fonoaudiologia da FOB - USP. Professora Associada do Departamento de Fonoaudiologia da FOB - USP.

******Trabalho Realizado na Clínica de Fonoaudiologia da FOB - USP.

Artigo Original de Pesquisa

Artigo Submetido a Avaliação por Pares

Conflito de Interesse: não

Recebido em 19.11.2008.

Revisado em 19.05.2009; 29.12.2009;

01.02.2010; 04.02.2010

Aceito para Publicação em 22.04.2010.

\section{Abstract}

Background: speech production in different modalities of oral prosthetic rehabilitation. Aim: to study the speech production of subjects submitted to different oral rehabilitation modalities. Method: 36 elderly individuals (average $=68$ years) of both gender were evaluated. Participants were divided in three groups: 13 subjects with natural teeth (A); 13 edentate using maxillary and mandibular conventional dentures (B); and 10 edentate using maxillary conventional dentures and mandibular implant-supported prosthesis (C). Prosthesis stability was evaluated by a dentist and speech samples were analyzed by five speech-language pathologists. In order to determine the frequency of speech sound alterations, the Percentage of Correct Consonants (PCC) was used. Results: few individuals presented speech alterations. Group C presented a higher occurrence of speech alterations (23.08\%). Locked articulation was present in all groups; the reduction in lip movement was observed for groups A and B; exaggerated articulation and absence of saliva control was observed for group C. A smaller Percentage of Correct Consonants value was observed for the linguodental phonemes, in groups B and C, followed by the alveolar phonemes. Group A presented the majority of individuals with no speech alterations. On the other hand, for groups B and C, lisp and tongue projection was frequently observed. No statistical difference was found between the groups. Most of the individuals in group B presented unsatisfactory prosthesis stability, but no association was identified between speech alterations and prosthesis stability. Conclusion: despite the small sample, the results of the study suggest that individuals using dentures present alterations in linguodental and alveolar phonemes. The type of prosthesis and its stability do not seem to interfere in speech production.

Key Words: Aging; Speech; Dental Prosthesis; Dental Implant.

\section{Resumo}

Tema: a produção da fala nas modalidades de reabilitação oral protética. Objetivo: verificar se o tipo de reabilitação oral interfere na produção da fala. Método: 36 idosos (média $=68$ anos), divididos em 3 grupos, foram avaliados: 13 com dentes naturais (A), 13 com prótese total mucosossuportada superior e inferior (B) e 10 com prótese total mucosossuportada superior e implantossuportada inferior (C). A estabilidade das próteses foi avaliada por um dentista e amostras de fala foram analisadas por 5 fonoaudiólogos. Para determinar a freqüência de alteração dos sons da fala utilizou-se o cálculo da Porcentagem de Consoantes Corretas (PCC). Resultados: observou-se poucos casos com alteração de fala, com maior freqüência no grupo C $(23,08 \%)$, sendo a articulação travada presente em todos os grupos, a redução dos movimentos labiais em dois grupos (A e B) e a articulação exagerada e a falta de controle salivar em um dos grupos (C e B). Quanto à $\mathrm{PCC}$, menor valor foi observado para os fones linguodentais nos grupos B e C (maior ocorrência de alteração), seguido dos fones alveolares, predominando casos sem alteração no grupo A, contrariamente aos demais grupos, sendo a projeção lingual e o ceceio as alterações mais encontradas. Não houve diferença entre os grupos e a maioria do grupo B estava com a prótese inferior insatisfatória, não havendo associação entre alteração de fala e prótese insatisfatória. Conclusão: apesar da amostra pequena, indivíduos reabilitados com prótese total apresentam alteração nos fones linguodentais e alveolares e o tipo de prótese, bem como a estabilidade desta parece não interferir na produção da fala.

Palavras-Chave: Envelhecimento; Fala. Prótese Dentária; Implante Dentário.

Referenciar este material como:

1 Rodrigues LCB, Pegoraro LF, Brasolotto AG, Berretin-Felix G, Genaro KF. A fala nas diferentes modalidades de reabilitação oral protética em idosos (Speech in different oral prosthetic rehabilitation modalities for elderly individuals). Pró-Fono Revista de Atualização Científica. 2010 abr-jun;22(2):151-6. 


\section{Introduction}

Speech involves acoustic and motor phenomena and the integrity of the structures involved is essential. The absence of teeth and the use of dental prosthesis may commit speech as teeth determine the production of sounds which may affect the emission of sounds, especially /s/ (1). Dentistry replaces teeth and restores aesthetics and function with prosthesis. The effect of such replacement and restoration on speech is determined by morphological characteristics and by the relationship between the prosthesis and the oral structures $(2,3)$.

During the prosthesis adaptation process, speech is one important aspect to be considered as phonetic alterations should be eliminated when present(2). However, there may be alterations in articulation and resonance(4) that occur due to the prolonged use of prosthesis. Changes in speech may occur when using the prosthesis for the first time or the when replacing it $(5,6,7)$. Speech symptoms may occur both in implant-supported and conventional prosthesis $(8,9,10)$. Higher satisfaction with the functions of chewing and speech, oral and aesthetic comfort, and quality of life has been reported with the use of the implantsupported prosthesis $(5,11,12,13,14)$.

The production of phonemes $/ \mathrm{s} /$ and $/ \mathrm{z} /$ are widely studied after oral rehabilitation and their alteration has been commonly reported $(15,16,17)$. This occurs due to the fine motor adjustments that the tongue performs during their emission - unlike vowels for which the shape of the prosthesis causes little impact on production (9). Aging is a factor to be considered and may difficult the prosthesis control during oral functions (18).

The current study analyzed the speech of elderly individuals with different types of oral rehabilitation in order to verify if the modality type interfered in speech production.

\section{Method}

This study was conducted after approval of the Committee on Research Ethics (protocol number 047/ 2007) of the institution following the recommendations of Resolution 196/96 of the National Health Council. This study was part of a larger project (Fundação de Amparo à Pesquisa do Estado de São Paulo - FAPESP (Ressearch Support Foundation of São Paulo State) in 91/2006).

Study participants were recruited from different Dental Clinics, Associations of Retired People, as well as family members of employees of the institution where the study was conducted. The following aspects were considered as exclusion criteria: history of neurological, head and neck oncologic, and psychiatric disease; laryngeal surgery; alcoholism or use of medication that causes dry mouth; craniofacial malformation; malocclusion; difficulty hearing or use of hearing aids; and cognitive impairment as measured by the Mini-Mental State Examination (19). Six participants were excluded - three due history of neurological disorder, two due to use of antidepressant, and one due to malocclusion.

The sample consisted of individuals of both genders aged between 60 and 82 years. Participants were divided into three groups: A - presence of natural teeth, at least until the second premolar; B - use of dual conventional denture; and $\mathrm{C}$ - use of upper and lower implant-supported denture (Table 1).

An interview was carried out in order to investigate the exclusion criteria. A Dental Surgeon verified the stability of the prostheses - considering unsatisfactory if they moved during speech production - as well as lesions in the oral mucosa. Subsequently, speech samples were recorded in a camera (Panasonic Palmcorder VJ98) on a tripod and positioned in front of and at one meter away from the individual.

TABLE 1. Sample characteristics regarding age, educational level and duration of use of prostheses in each group.

\begin{tabular}{|c|c|c|c|c|c|c|c|c|}
\hline \multirow{3}{*}{ Group } & \multirow{3}{*}{$\mathbf{n}$} & \multirow{3}{*}{\begin{tabular}{l}
\multicolumn{1}{c}{ Age } \\
Mean (Minimum- \\
Maximum)
\end{tabular}} & \multicolumn{4}{|c|}{ Educational Level } & \multirow{2}{*}{\multicolumn{2}{|c|}{$\begin{array}{l}\text { Duration of prsotheses use } \\
\text { Mean (Minimum-Maximum) }\end{array}$}} \\
\hline & & & \multirow[b]{2}{*}{ Iliterate } & \multirow{2}{*}{$\begin{array}{c}\text { Basic } \\
\text { Education }\end{array}$} & \multirow{2}{*}{$\begin{array}{l}\text { High } \\
\text { School }\end{array}$} & \multirow{2}{*}{ College } & & \\
\hline & & & & & & & Upper & Lower \\
\hline A & 13 & $65 \mathrm{y} 11 \mathrm{~m}(60-80$ years $)$ & ---- & 2 & 11 & ---- & ---- & ---- \\
\hline B & 13 & $70 y 5 m$ (61-82 years) & 2 & 6 & 4 & 1 & $7 y 3 m(1 m-22 y)$ & $7 y 3 m(1 m-22 y)$ \\
\hline C & 10 & $68 y 6 m(60-74$ years $)$ & 2 & 6 & 1 & 1 & $3 y 10 m(2 y-8 y)$ & $3 y 6 m(2 y-8 y)$ \\
\hline TOTAL & 36 & $68 y 3 m$ (60-82 years) & 4 & 14 & 16 & 2 & $5 y 9 m(1 m-22 y)$ & 5y7m (1m-22y) \\
\hline
\end{tabular}


We used a sample of spontaneous speech with questions of reference and repetition of words and phrases. The samples were analyzed by five experienced Speech-Language Pathologists following a pre-established guideline and considering the opinion of the majority of them.

Speech-Language Pathologists were asked to examine the spontaneous speech and to identify: exaggerated or closed articulation; reduction of lip movements; lack of salivary control; repetition of

PCC $=\underline{\text { number of correct consonants }} \times 100$ number of incorrect + number of correct consonants

words and phrases analyzing the frequency and type of alteration - such as change in the articulation point, tong thrust, lisp, mandibular deviation or articulatory distortion. The frequency of alteration for each phoneme was calculated using the Percentage of Consonants Correct (PCC) (20):

The inter-judge reliability regarding the presence or absence of alterations in spontaneous speech, the PCC for each phoneme in different groups, and the types of alteration was calculated through the Kappa test. ANOVAs were used to compare the PCC and the types of alterations among the groups. The Fisher's exact test was used to test the association between presence or absence of alteration in spontaneous speech and stability of the prostheses. The adopted significance level was of $5 \%$.

\section{Results}

Speech-Language Pathologists identified a higher frequency of alteration in group $\mathrm{C}$ as compared to the other groups $(\mathrm{A}=23.08 \%, \mathrm{~B}=$ $15.38 \%, \mathrm{C}=30.00 \%)$. Closed articulation was observed in all groups $(\mathrm{A}=15.38 \% ; \mathrm{B}=7.69 \%, \mathrm{C}=$ $20.00 \%$ ) whereas reduction of lip movements was only observed in two groups $(\mathrm{A}=\mathrm{B}=7.69 \%$ and $7.69 \%$ ). Exaggerated articulation and lack of salivary control were observed in only one group $(\mathrm{C}=$ $10.00 \%$ and $\mathrm{B}=7.69 \%$, respectively). A single subject (from group B) presented more than one type of alteration (closed articulation and inability to control saliva).

Inter-judge reliability regarding PCC ranged from regular to almost perfect (Kappa $\sim$ s coefficient between 0.35 and 1.00). The median of the five PCC values attributed by the judges for each phoneme was calculated. Results compared among the groups (Table 2) showed no statistical difference. Lower PCC values were observed for dental phonemes in groups $\mathrm{B}$ and $\mathrm{C}$ - i.e. higher incidence of alteration - followed by alveolar phonemes.

Regarding the types of alterations, there was substantial agreement among the judges. Although no statistically significant among-groups difference was observed regarding the frequency of alteration, the highest frequencies were observed for groups $\mathrm{B}$ and $\mathrm{C}$ (Table 3). The exchange of articulatory point was observed in group $\mathrm{C}$. Tongue thrust and lisp were observed in all groups - predominantly in groups B and C. Mandibular deviation was observed in groups A and $\mathrm{C}$.

There was no association between the presence or absence of speech impairment and stability of dentures (Table 4), both for superior and inferior prosthesis, prevailing lack of alteration in speech and satisfactory prosthesis. 
TABLE 2. Median, minimum and maximum PCC values for each phoneme in different groups and the ANOVA outcome.

\begin{tabular}{|c|c|c|c|c|c|}
\hline \multirow{2}{*}{ Phonemic group } & \multirow{2}{*}{ Phoneme } & \multicolumn{4}{|c|}{ Groups } \\
\hline & & A & B & C & $\mathrm{P}$ \\
\hline \multirow{3}{*}{ Bilabial } & [p] & $\begin{array}{c}100 \% \\
(80 \%-100 \%)\end{array}$ & $\begin{array}{c}100 \% \\
(80 \%-100 \%)\end{array}$ & $\begin{array}{c}100 \% \\
(10 \%-100 \%)\end{array}$ & 0,3489 \\
\hline & [b] & $\begin{array}{c}100 \% \\
(80-100 \%)\end{array}$ & $\begin{array}{c}100 \% \\
(100 \text { a } 100 \%)\end{array}$ & $\begin{array}{c}100 \% \\
(50-100 \%)\end{array}$ & 0,0646 \\
\hline & {$[\mathrm{m}]$} & $\begin{array}{c}100 \% \\
(100 \text { a } 100 \%)\end{array}$ & $\begin{array}{c}100 \% \\
(100 \text { a } 100 \%)\end{array}$ & $\begin{array}{c}100 \% \\
(100 \text { a } 100 \%)\end{array}$ & 1,0000 \\
\hline \multirow{2}{*}{ Labiodental } & {$[\mathrm{f}]$} & $\begin{array}{c}100 \% \\
(0-100 \%)\end{array}$ & $\begin{array}{c}100 \% \\
(50-100 \%)\end{array}$ & $\begin{array}{c}100 \% \\
(0-100 \%)\end{array}$ & 1,0000 \\
\hline & {$[\mathrm{v}]$} & $\begin{array}{c}100 \% \\
(0-100 \%)\end{array}$ & $\begin{array}{c}100 \% \\
(0-100 \%)\end{array}$ & $\begin{array}{c}100 \% \\
(0-100 \%)\end{array}$ & 0,4249 \\
\hline \multirow{3}{*}{ Linguodental } & {$[\mathrm{t}]$} & $\begin{array}{c}100 \% \\
(0-100 \%)\end{array}$ & $\begin{array}{c}88 \% \\
(0-100 \%)\end{array}$ & $\begin{array}{c}82 \% \\
(0-100 \%)\end{array}$ & 0,5852 \\
\hline & [d] & $\begin{array}{c}100 \% \\
(0-100 \%)\end{array}$ & $\begin{array}{c}100 \% \\
(0-100 \%)\end{array}$ & $\begin{array}{c}96 \% \\
(0-100 \%)\end{array}$ & 0,6340 \\
\hline & {$[\mathrm{n}]$} & $\begin{array}{c}100 \% \\
(0-100 \%)\end{array}$ & $\begin{array}{c}100 \% \\
(0-100 \%)\end{array}$ & $\begin{array}{c}100 \% \\
(0-100 \%)\end{array}$ & 0,8047 \\
\hline \multirow{5}{*}{ Alveolar } & {$[\mathrm{s}]$} & $\begin{array}{c}100 \% \\
(0-100 \%)\end{array}$ & $\begin{array}{c}100 \% \\
(0-100 \%)\end{array}$ & $\begin{array}{c}100 \% \\
(0-100 \%)\end{array}$ & 0,3837 \\
\hline & {$[\mathrm{z}]$} & $\begin{array}{c}100 \% \\
(0-100 \%)\end{array}$ & $\begin{array}{c}100 \% \\
(0-100 \%)\end{array}$ & $\begin{array}{c}100 \% \\
(0-100 \%)\end{array}$ & 0,1112 \\
\hline & {$[1]$} & $\begin{array}{c}100 \% \\
(33-100 \%)\end{array}$ & $\begin{array}{c}100 \% \\
(0-100 \%)\end{array}$ & $\begin{array}{c}100 \% \\
(0-100 \%)\end{array}$ & 0,5179 \\
\hline & {$[\mathrm{r}]$} & $\begin{array}{c}100 \% \\
(14-100 \%)\end{array}$ & $\begin{array}{c}100 \% \\
(0-100 \%)\end{array}$ & $\begin{array}{c}100 \% \\
(0-100 \%)\end{array}$ & 0,4174 \\
\hline & $\{\mathrm{S}\}$ & $\begin{array}{c}100 \% \\
(0-100 \%)\end{array}$ & $\begin{array}{c}100 \% \\
(0-100 \%)\end{array}$ & $\begin{array}{c}100 \% \\
(0-100 \%)\end{array}$ & 0,1248 \\
\hline \multirow{4}{*}{ Palatal } & {$[?]$} & $\begin{array}{c}100 \% \\
(0-100 \%)\end{array}$ & $\begin{array}{c}100 \% \\
(0-100 \%)\end{array}$ & $\begin{array}{c}100 \% \\
(0-100 \%)\end{array}$ & 0,0606 \\
\hline & [?] & $\begin{array}{c}100 \% \\
(0-100 \%)\end{array}$ & $\begin{array}{c}100 \% \\
(0-100 \%)\end{array}$ & $\begin{array}{c}100 \% \\
(0-100 \%)\end{array}$ & 0,4249 \\
\hline & [?] & $\begin{array}{c}100 \% \\
(0-100 \%)\end{array}$ & $\begin{array}{c}100 \% \\
(0-100 \%)\end{array}$ & $\begin{array}{c}100 \% \\
(0-100 \%)\end{array}$ & 0,2798 \\
\hline & {$[\lambda]$} & $\begin{array}{c}100 \% \\
(0-100 \%)\end{array}$ & $\begin{array}{c}100 \% \\
(0-100 \%)\end{array}$ & $\begin{array}{c}100 \% \\
(0-100 \%)\end{array}$ & 0,2798 \\
\hline \multirow{4}{*}{ Velar } & {$[\mathrm{k}]$} & $\begin{array}{c}100 \% \\
(38-100 \%)\end{array}$ & $\begin{array}{c}100 \% \\
(0-100 \%)\end{array}$ & $\begin{array}{c}100 \% \\
(0-100 \%)\end{array}$ & 0,5030 \\
\hline & {$[\mathrm{g}]$} & $\begin{array}{c}100 \% \\
(71-100 \%)\end{array}$ & $\begin{array}{c}100 \% \\
(100-100 \%)\end{array}$ & $\begin{array}{c}100 \% \\
(100-100 \%)\end{array}$ & 1,0000 \\
\hline & {$[\mathrm{R}]$} & $\begin{array}{c}100 \% \\
(100-100 \%)\end{array}$ & $\begin{array}{c}100 \% \\
(17-100 \%)\end{array}$ & $\begin{array}{c}100 \% \\
(0-100 \%)\end{array}$ & 1,0000 \\
\hline & $\{\mathrm{R}\}$ & $\begin{array}{c}100 \% \\
(0-100 \%)\end{array}$ & $\begin{array}{c}100 \% \\
(0-100 \%)\end{array}$ & $\begin{array}{c}100 \% \\
(0-100 \%)\end{array}$ & 0,5570 \\
\hline
\end{tabular}


TABLE 3. Frequency of alteration types, inter-judge reliability and analysis of variance of frequency of alteration among groups.

\begin{tabular}{|c|c|c|c|c|}
\hline \multirow{2}{*}{ Alterations } & \multicolumn{3}{|c|}{ GROUPS } & \multirow{2}{*}{$P$} \\
\hline & $A(n=13)$ & $B(n=13)$ & $\mathrm{C}(\mathrm{n}=10)$ & \\
\hline No alteration & $\begin{array}{c}61,54 \% \\
(n=8)\end{array}$ & $\begin{array}{c}30,77 \% \\
(n=4)\end{array}$ & $\begin{array}{c}20,00 \% \\
(\mathrm{n}=2)\end{array}$ & 0,1011 \\
\hline Exchange of articulatory point & $\begin{array}{l}0,00 \% \\
(\mathrm{n}=0)\end{array}$ & $\begin{array}{l}0,00 \% \\
(\mathrm{n}=0)\end{array}$ & $\begin{array}{c}10,00 \% \\
(\mathrm{n}=1)\end{array}$ & 0,2798 \\
\hline Tongue thrust & $\begin{array}{c}23,07 \% \\
(n=3)\end{array}$ & $\begin{array}{c}61,54 \% \\
(n=8)\end{array}$ & $\begin{array}{c}60,00 \% \\
(n=6)\end{array}$ & 0,0960 \\
\hline Lisp & $\begin{array}{c}15,38 \% \\
(n=2)\end{array}$ & $\begin{array}{c}30,77 \% \\
(\mathrm{n}=4)\end{array}$ & $\begin{array}{c}30,00 \% \\
(n=3)\end{array}$ & 0,6267 \\
\hline Mandibular deviation & $\begin{array}{c}23,07 \% \\
(n=3)\end{array}$ & $\begin{array}{l}0,00 \% \\
(\mathrm{n}=0)\end{array}$ & $\begin{array}{c}20,00 \% \\
(\mathrm{n}=2)\end{array}$ & 0,2019 \\
\hline Articulatory distortion & $\begin{array}{l}0,00 \% \\
(\mathrm{n}=0)\end{array}$ & $\begin{array}{l}0,00 \% \\
(\mathrm{n}=0)\end{array}$ & $\begin{array}{l}0,00 \% \\
(n=0)\end{array}$ & 1,0000 \\
\hline
\end{tabular}

TABLE 4. Association between alteration in spontaneous speech and prostheses stability.

\begin{tabular}{ccccccc}
\hline Speech & \multicolumn{3}{c}{ Upper Prosthesis } & \multicolumn{3}{c}{ Lower Prosthesis } \\
\cline { 2 - 3 } alteration & Satisfactory & Unsatisfactory & Total & Satisfactory & Unsatisfactory & Total \\
\hline \multirow{2}{*}{ Absent } & $52,17 \%$ & $26,08 \%$ & $78,25 \%$ & $43,47 \%$ & $34,78 \%$ & $78,26 \%$ \\
& $(\mathrm{n}=12)$ & $(\mathrm{n}=6)$ & $(\mathrm{n}=18)$ & $(\mathrm{n}=10)$ & $(\mathrm{n}=8)$ & $(\mathrm{n}=18)$ \\
& $8,69 \%$ & $13,04 \%$ & $21,73 \%$ & $17,39 \%$ & $4,34 \%$ & $21,74 \%$ \\
Present & $(\mathrm{n}=2)$ & $(\mathrm{n}=3)$ & $(\mathrm{n}=5)$ & $(\mathrm{n}=4)$ & $(\mathrm{n}=1)$ & $(\mathrm{n}=5)$ \\
& $60,86 \%$ & $39,12 \%$ & $100,00 \%$ & $60,86 \% \%$ & $39,12 \%$ & $100,00 \%$ \\
& $(\mathrm{n}=14)$ & $(\mathrm{n}=9)$ & $(\mathrm{n}=23)$ & $(\mathrm{n}=14)$ & $(\mathrm{n}=9)$ & $(\mathrm{n}=23)$ \\
\hline \multirow{2}{*}{ Total } & \multicolumn{3}{c}{ Fisher $=0,61056$} & & &
\end{tabular}

\section{Discussion}

The teeth play an important role in speech production, allowing the emission of several phonemes (21). With the loss of teeth, there is possibility of replacement with the use of prosthesis adapted by Dentists in order to restore aesthetics and function and to offer better quality of life. Dental conditions and different rehabilitation procedures can interfere with speech. Thus, this study examined such functions in cases with different types of oral rehabilitation.

We analyzed the speech of individuals with natural teeth and of users of denture who were over 60 years of age as this type of rehabilitation (denture) is common in this age group. It was more difficult to compose the group with natural teeth, a fact attributed to lack of information about teeth care as many participants reported that, faced with dental problems, the extraction was very common. These findings regarding oral health condition of the elderly agree with Roncalli (22). Moreover, among the rehabilitated participants, there were illiterate individuals and the educational level up to Basic Education was the most frequent one. In contrast, in the group of individuals with natural teeth, there were no illiterate participants and the High School educational level was predominant. This data points to the influence of socioeconomic status on oral health.

The perceptual-auditory speech analysis is a procedure that depends on the experience of the evaluator. Thus, experienced judges and a consensus among them are extremely necessary. The analysis of two or more judges $(4,9,23)$ is recommended for results reliability. Thus, the speech samples of the current study were analyzed by five Speech-Language Pathologists with experience in phonetic speech analysis. The opinion of the majority of the judges was considered on the 
final analysis. The judges identified a few cases with alterations in speech, being those most frequent in group C. Closed articulation was observed in the 3 groups, reduction of lip movements in groups A and B, lack of salivary control in group B, and exaggerated articulation in group C.

The results of closed articulation agrees with the study by Cunha, Felicio and Bataglion(7) who reported this articulation pattern after the fitting of new prostheses. However, as such pattern was also observed in dentate participants, the possibility that this condition was present before oral rehabilitation is raised as Sansone et al. (5) found that treatment with implant-supported prosthesis implies no functional changes.

The analysis of frequency of alterations observed for each phoneme was based on the PCC (20) in order to obtain quantitative data of speech impairment. The PCC were in agreement among the judges. The among-groups comparison showed no significant difference. This can be attributed to sample size as individual analysis revealed lower PCC values in groups B and C for alveolar and dental phonemes which agrees with studies showing that these are the mostly altered phonemes after insertion of total dentures $(2,11,15,16)$.

There was agreement among judges regarding the identification of articulation point exchange, tongue thrust, lisp and mandibular deviation with a prevalence of cases with no alteration among the dentate group. In contrast, in the group of individuals who received rehabilitation, the tongue thrust and lisp were frequent alterations. This data is in agreement with a study which indicated that such alterations may occur in users of dental prostheses (7). Thus, this suggests that the prosthesis may interfere with speech production; however, further studies involving a larger number of cases are necessary.

One factor that may affect speech is the condition of the prosthesis. However, this study showed no association between speech impairment and stability of the prosthesis. Most users of upper and lower prostheses showed no speech impairment - which was satisfactory. However, there were cases with no speech impairment and unsatisfactory prosthesis.
Another aspect to consider is the possibility that the duration of prosthesis use may influence speech. A study reported that the use of conventional prostheses for a long period can harm the adjustment of new prostheses and may require professional help (11). In the current study, three patients have used prostheses for over 10 years and, on the individual analysis, two of them presented no speech alteration. In addition, some patients with shorter period of prostheses use showed the same alterations as those with prolonged use. An analysis excluding these three cases showed no change in results of the current study. It is noteworthy that a case with 15 years of prostheses use - which were unsatisfactory presented altered speech, was illiterate and presented the Mini-Mental State Examination at the lower limit. This suggests that other factors contribute to speech impairment, interfering on the ability to control the prosthesis during several oral functions (18).

We should also raise the influence of education on speech impairment because, among the rehabilitated participants in whom the speech impairment prevailed, there were illiterate participants and the highest concentration of participants who had completed Basic Education. However, the sample size did not allow a statistical analysis in this regard.

Thus, we must also consider the adaptability of the stomatognathic system to the new oral condition, even in the elderly, justifying the results of this study, in view of the low frequency of cases with speech impairment. This fact is important because such population suffers from discrimination and because communication is critical in maintaining the quality of life in this phase.

This was an initial study which identified the need for new studies aiming to increase the sample size and to analyze variables related to aging - such as muscular and hearing aspects - which can also influence on the communication process and on the socio-cultural level.

The process of manufacturing and fitting of prostheses aims to restore aesthetics and function. Therefore, the professional with expertise in oral functions should be inserted in the team that assists prostheses users. 


\section{Conclusions}

The analysis of speech production of 36 elderly individuals showed that the type of prosthesis and its stability does not seem to interfere with speech production, having been verified:

- Increased frequency of impairments in spontaneous speech in group $\mathrm{C}$; closed articulation in all groups; reduction of lip movements in groups $\mathrm{A}$ and $\mathrm{B}$; exaggerated articulation and lack of salivary control in rehabilitated individuals;

\section{References}

1. Ghi H, McGivney GP. Influence of tooth proprioception on speech articulation. J Pros Den. 1979;42(6):609-13.

2. Tanaka H. Speech patterns of edentulous patients and morphology of the palate in relation to phonetics. J Prosthet Dent. $1973 ; 29(1): 16-28$.

3. Russi S, Lombardo JG, Nogueira SS. Fonética e prótese total - estudo palatográfico dos sons "G", "R" e "L". RGO. 1992;40(6):417-20.

4. Özbek M, Tuluno Lu B, Özkan S, Öktemer M. Evaluation of articulation of turkish phonemes after removable partial denture application. Braz Dent J. 2003;14(2):125-31.

5. Sansone KM, Filho HN, Berretin-Félix G, Brasolotto AG. Oral myofunctional and vocal characteristics in subjects subjected to oral rehabilitation with osseointegrated implants. Clin Oral Impl Res. 2006;17(3):328-30.

6. Schiffman S. Taste and smell loses in normal aging and disease. JAMA 1997,278(16):1357-62.

7. Cunha CC; Felício CM de; Bataglion C. Condições miofuncionais orais em usuários de próteses totais. PróFono. 1998;11(1):21-6.

8. Felício CM. Fala: um índice sobre adaptação às próteses totais. Pró-fono. 1998;10(1):66-72.

9. Heydecke G, McFarland DH, Feine JS, Lund JP. Speech with maxillary implant prostheses: ratings of articulation. J Dent Res. 2004;83(3):236-40.

10. DeBoer J. Edentulous implants: overdenture versus fixed. J Prosthet Dent. 1993;69(4):386-90.

11. Molly L, Nackaerts O, Vandewiele K, Manders E, Van Steenberghe D, Jacobs R. Speech adaptation after treatment of full edentulism through immediate loaded implant protocols. Clin Oral Impl Res. 2008;19(1):86-90.

12. Cibirka RM, Razzoog M, Lang BR. Critical evaluation of patient responses to dental implant therapy. J Prosthet Dent. 1997;78(6):574-81.

13. Yi SW, Carlsson GE, Ericsson I, Kim CK. Patient evaluation of treatment with fixed implant-supported partial dentures. J Oral Rehabil. 2001;28(11):998-1002.
- No among-groups differences regarding PCC. However, a decreased value for dental phonemes among the rehabilitated cases was observed - with a higher occurrence of alteration - followed by alveolar phonemes. Tongue thrust and lisp the most frequent alterations;

- No association between changes in speech production and unsatisfactory prosthesis.
14. Berretin-Felix G, Nary Filho H, Padovani CR, Machado WM. A longitudinal study of quality of life of elderly with mandibular implant-supported fixed prostheses. Clin Oral Impl Res. 2008;19(7):704-8.

15. Manders E; Jacobs R; Nackaerts O; Van Looy C; Lembrechts D. The influence of oral implant-supported prostheses on articulation and myofunction. Acta Otorhinol Belg. 2003;57(1):73-7.

16. Runte C, Lawerino M, Dirksen D, Bollmann F, Lamprecht-Dinnesen A, Seifert E. The influence of maxillary central incisor position in complete dentures on [s] sound production. J Prosthet Dent. 2001;85(5):48595 .

17. Aasland WA, Baum SR, McFarland DH. Electropalatographic, acoustic, and perceptual data on adaptation to a palatal pertubation. J Acoust Soc Am. 2006;119(4):2372-81.

18. Scott BJ, Hunter RV. Creating complete dentures that are stable in function. Dent Update. 2008;35(4):259-62, 265-7.

19. Lourenço RA, Veras RP. Mini-Exame do Estado Mental: características de medida da escala. Rev Saúde Pública. 2006;40(4):712-9.

20. Shriberg LD, Kwiatkowski J. Phonological disorders III: A procedure for assessing severity of involvement. J Speech Hear Dis. 1982;47(3):256-70.

21. McFarland DH, Baum SR, Chabot C. Speech compensation of structural modifications of the oral cavity. J Acoust Soc Am. 1996;100(2Pt1):1093-104.

22. Roncalli AG. Epidemiologia e saúde bucal coletiva: um caminhar compartilhado. Cien Saude Colet. 2006; 11(1):105-14.

23. Baum SR, McFalard DH. The development of speech adaptation to artificial palate. J Acoust Soc Am. 1997;102(4):2353-9. 